\title{
Class Frizzled GPCRs (version 2019.4) in the IUPHAR/BPS Guide to Pharmacology Database
}

\author{
Elisa Arthofer ${ }^{1}$, Jacomijn Dijksterhuis², Belma Hot², Paweł Kozielewicz², Matthias Lauth ${ }^{3}$, Jessica Olofsson², \\ Julian Petersen², Tilman Polonio², Gunnar Schulte ${ }^{2}$, Katerina Strakova ${ }^{2}$, Jana Valnohova ${ }^{2}$ and Shane Wright ${ }^{2}$ \\ 1. National Institute of Child Health and Human Development, USA \\ 2. Karolinska Institutet, Sweden \\ 3. Philipps-Universität Marburg, Germany
}

\begin{abstract}
Receptors of the Class Frizzled (FZD, nomenclature as agreed by the NC-IUPHAR subcommittee on the Class Frizzled GPCRs [156]), are GPCRs originally identified inDrosophila [17], which are highly conserved across species. While SMO shows structural resemblance to the $10 \mathrm{FZDs}$, it is functionally separated as it mediates effects in the Hedgehog signaling pathway [156]. FZDs are activated by WNTs, which are cysteinerich lipoglycoproteins with fundamental functions in ontogeny and tissue homeostasis. FZD signalling was initially divided into two pathways, being either dependent on the accumulation of the transcription regulator $\beta$ catenin or being $\beta$-catenin-independent (often referred to as canonicalvs. non-canonical WNT/FZD signalling, respectively). WNT stimulation of FZDs can, in cooperation with the low density lipoprotein receptors LRP5 (O75197) and LRP6 (O75581), lead to the inhibition of a constitutively active destruction complex, which results in the accumulation of $\beta$-catenin and subsequently its translocation to the nucleus. $\beta$-Catenin, in turn, modifies gene transcription by interacting with TCF/LEF transcription factors. $\beta$-Catenin-independent FZD signalling is far more complex with regard to the diversity of the activated pathways. WNT/FZD signalling can lead to the activation of heterotrimeric $G$ proteins [28, 159, 135], the elevation of intracellular calcium [164], activation of cGMP-specific PDE6 [2] and elevation of CAMP as well as RAC-1, JNK, Rho and Rho kinase signalling 48]. Novel resonance energy transfer-based tools have allowed the study of the GPCR-like nature of FZDs in greater detail. Upon ligand stimulation, FZDs undergo conformational changes and signal via heterotrimeric $\mathrm{G}$ proteins [213, 214]. Furthermore, the phosphoprotein Dishevelled constitutes a key player in WNT/FZD signalling. Importantly, FZDs exist in at least two distinct conformational states that regulate the pathway selection [214]. As with other GPCRs, members of the Frizzled family are functionally dependent on the arrestin scaffolding protein for internalization [19], as well as for $\beta$-catenin-dependent [12] and -independent [80, 13] signalling. The pattern of cell signalling is complicated by the presence of additional ligands, which can enhance or inhibit FZD signalling (secreted Frizzled-related proteins (sFRP), Wnt-inhibitory factor (WIF), sclerostin or Dickkopf (DKK)), as well as modulatory (co)-receptors with Ryk, ROR1, ROR2 and Kremen, which may also function as independent signalling proteins.
\end{abstract}

\section{Contents}

This is a citation summary for Class Frizzled GPCRs in the Guide to Pharmacology database (GtoPdb). It exists purely as an adjunct to the database to facilitate the recognition of citations to and from the database by citation analyzers. Readers will almost certainly want to visit the relevant sections of the database which are given here 
under database links.

GtoPdb is an expert-driven guide to pharmacological targets and the substances that act on them. GtoPdb is a reference work which is most usefully represented as an on-line database. As in any publication this work should be appropriately cited, and the papers it cites should also be recognized. This document provides a citation for the relevant parts of the database, and also provides a reference list for the research cited by those parts.

Please note that the database version for the citations given in GtoPdb are to the most recent preceding version in which the family or its subfamilies and targets were substantially changed. The links below are to the current version. If you need to consult the cited version, rather than the most recent version, please contact the GtoPdb curators.

\section{Database links}

\section{Class Frizzled GPCRs}

http://www.guidetopharmacology.org/GRAC/FamilyDisplayForward?familyld=25

Introduction to Class Frizzled GPCRs

http://www.guidetopharmacology.org/GRAC/FamilyIntroductionForward?familyld=25

Receptors

$\mathrm{FZD}_{1}$

http://www.guidetopharmacology.org/GRAC/ObjectDisplayForward?objectld=229

$\mathrm{FZD}_{2}$

http://www.guidetopharmacology.org/GRAC/ObjectDisplayForward?objectld=230

$\mathrm{FZD}_{3}$

http://www.guidetopharmacology.org/GRAC/ObjectDisplayForward?objectld=231

$\mathrm{FZD}_{4}$

http://www.guidetopharmacology.org/GRAC/ObjectDisplayForward?objectld=232

$\mathrm{FZD}_{5}$

http://www.guidetopharmacology.org/GRAC/ObjectDisplayForward?objectld=233

$\mathrm{FZD}_{6}$

http://www.guidetopharmacology.org/GRAC/ObjectDisplayForward?objectld=234

$\mathrm{FZD}_{7}$

http://www.guidetopharmacology.org/GRAC/ObjectDisplayForward?objectld=235

$\mathrm{FZD}_{8}$

http://www.guidetopharmacology.org/GRAC/ObjectDisplayForward?objectld=236

$\mathrm{FZD}_{9}$

http://www.guidetopharmacology.org/GRAC/ObjectDisplayForward?objectld=237

$\mathrm{FZD}_{10}$

http://www.guidetopharmacology.org/GRAC/ObjectDisplayForward?objectld=238

SMO

http://www.guidetopharmacology.org/GRAC/ObjectDisplayForward?objectld=239

\section{References}

1. Acevedo VD, Gangula RD, Freeman KW, Li R, Zhang Y, Wang F, Ayala GE, Peterson LE, Ittmann M and Spencer DM. (2007) Inducible FGFR-1 activation leads to irreversible prostate adenocarcinoma and an epithelial-to-mesenchymal transition. Cancer Cell 12: 559-71 [PMID:18068632]

2. Ahumada A, Slusarski DC, Liu X, Moon RT, Malbon CC and Wang HY. (2002) Signaling of rat Frizzled-2 through phosphodiesterase and cyclic GMP. Science 298: 2006-10 [PMID:12471263]

3. Albers J, Schulze J, Beil FT, Gebauer M, Baranowsky A, Keller J, Marshall RP, Wintges K, Friedrich FW 
and Priemel M et al.. (2011) Control of bone formation by the serpentine receptor Frizzled-9.J. Cell Biol. 192: 1057-72 [PMID:21402791]

4. Angers $S$ and Moon RT. (2009) Proximal events in Wnt signal transduction.Nat. Rev. Mol. Cell Biol. 10: 468-77 [PMID:19536106]

5. Arthofer E, Hot B, Petersen J, Strakova K, Jäger S, Grundmann M, Kostenis E, Gutkind JS and Schulte G. (2016) WNT Stimulation Dissociates a Frizzled 4 Inactive-State Complex with Go12/13. Mol. Pharmacol. 90: 447-59 [PMID:27458145]

6. AstraZeneca. AZD8542.

7. Bengochea A, de Souza MM, Lefrançois L, Le Roux E, Galy O, Chemin I, Kim M, Wands JR, Trepo C and Hainaut $\mathrm{P}$ et al.. (2008) Common dysregulation of Wnt/Frizzled receptor elements in human hepatocellular carcinoma. Br. J. Cancer 99: 143-50 [PMID:18577996]

8. Bethge N, Honne H, Hilden V, Trøen G, Eknæs M, Liestøl K, Holte H, Delabie J, Smeland EB and Lind GE. (2013) Identification of highly methylated genes across various types of B-cell non-hodgkin lymphoma. PLoS ONE 8: e79602 [PMID:24260260]

9. Borello U, Berarducci B, Murphy P, Bajard L, Buffa V, Piccolo S, Buckingham M and Cossu G. (2006) The Wnt/beta-catenin pathway regulates Gli-mediated Myf5 expression during somitogenesis. Development 133: 3723-32 [PMID:16936075]

10. Borello U, Buffa V, Sonnino C, Melchionna R, Vivarelli E and Cossu G. (1999) Differential expression of the Wnt putative receptors Frizzled during mouse somitogenesis. Mech. Dev. 89: 173-7 [PMID:10559494]

11. Bravo DT, Yang YL, Kuchenbecker K, Hung MS, Xu Z, Jablons DM and You L. (2013) Frizzled-8 receptor is activated by the Wnt-2 ligand in non-small cell lung cancer. BMC Cancer 13: 316 [PMID:23815780]

12. Bryja V, Gradl D, Schambony A, Arenas E and Schulte G. (2007) Beta-arrestin is a necessary component of Wnt/beta-catenin signaling in vitro and in vivo. Proc. Natl. Acad. Sci. U.S.A. 104: 6690-5 [PMID:17426148]

13. Bryja V, Schambony A, Cajánek L, Dominguez I, Arenas E and Schulte G. (2008) Beta-arrestin and casein kinase 1/2 define distinct branches of non-canonical WNT signalling pathways. EMBO Rep. 9: 1244-50 [PMID:18953287]

14. Byrne EFX, Sircar R, Miller PS, Hedger G, Luchetti G, Nachtergaele S, Tully MD, Mydock-McGrane L, Covey DF and Rambo RP et al.. (2016) Structural basis of Smoothened regulation by its extracellular domains. Nature 535: 517-522 [PMID:27437577]

15. Canny CL and Oliver GL. (1976) Fluorescein angiographic findings in familial exudative vitreoretinopathy. Arch. Ophthalmol. 94: 1114-20 [PMID:947162]

16. Carmon KS and Loose DS. (2008) Secreted frizzled-related protein 4 regulates two Wnt7a signaling pathways and inhibits proliferation in endometrial cancer cells. Mol. Cancer Res. 6: 1017-28 [PMID:18567805]

17. Chan SD, Karpf DB, Fowlkes ME, Hooks M, Bradley MS, Vuong V, Bambino T, Liu MY, Arnaud CD and Strewler GJ et al.. (1992) Two homologs of the Drosophila polarity gene frizzled (fz) are widely expressed in mammalian tissues. J. Biol. Chem. 267: 25202-7 [PMID:1334084]

18. Chen M, Wang J, Lu J, Bond MC, Ren XR, Lyerly HK, Barak LS and Chen W. (2009) The anti-helminthic niclosamide inhibits Wnt/Frizzled1 signaling. Biochemistry 48: 10267-74 [PMID:19772353]

19. Chen W, Kirkbride KC, How T, Nelson CD, Mo J, Frederick JP, Wang XF, Lefkowitz RJ and Blobe GC. (2003) Beta-arrestin 2 mediates endocytosis of type III TGF-beta receptor and down-regulation of its signaling. Science 301: 1394-7 [PMID:12958365]

20. Chen W, ten Berge D, Brown J, Ahn S, Hu LA, Miller WE, Caron MG, Barak LS, Nusse R and Lefkowitz RJ. (2003) Dishevelled 2 recruits beta-arrestin 2 to mediate Wnt5A-stimulated endocytosis of Frizzled 4. Science 301: 1391-1394 [PMID:12958364]

21. Chien AJ, Conrad WH and Moon RT. (2009) A Wnt survival guide: from flies to human disease J. Invest. Dermatol. 129: 1614-27 [PMID:19177135]

22. Clevers $\mathrm{H}$ and Nusse R. (2012) Wnt/ $\beta$-catenin signaling and disease.Cell 149: 1192-205 [PMID:22682243]

23. Corcoran RB and Scott MP. (2006) Oxysterols stimulate Sonic hedgehog signal transduction and 
proliferation of medulloblastoma cells. Proc. Natl. Acad. Sci. U.S.A. 103: 8408-13 [PMID:16707575]

24. Criswick VG and Schepens CL. (1969) Familial exudative vitreoretinopathy.Am. J. Ophthalmol. 68: 578-94 [PMID:5394449]

25. Dann CE, Hsieh JC, Rattner A, Sharma D, Nathans J and Leahy DJ. (2001) Insights into Wnt binding and signalling from the structures of two Frizzled cysteine-rich domains. Nature 412: 86-90 [PMID:11452312]

26. Daudet N, Ripoll C, Molès JP and Rebillard G. (2002) Expression of members of Wnt and Frizzled gene families in the postnatal rat cochlea. Brain Res. Mol. Brain Res. 105: 98-107 [PMID:12399112]

27. Dickins EM and Salinas PC. (2013) Wnts in action: from synapse formation to synaptic maintenance.Front Cell Neurosci 7: 162 [PMID:24223536]

28. Dijksterhuis JP, Petersen J and Schulte G. (2013) WNT/Frizzled signaling: receptor-ligand selectivity with focus on FZD-G protein signaling and its physiological relevance. Br J Pharmacol[PMID:24032637]

29. Dufourcq P, Leroux L, Ezan J, Descamps B, Lamazière JM, Costet P, Basoni C, Moreau C, Deutsch U and Couffinhal T et al.. (2008) Regulation of endothelial cell cytoskeletal reorganization by a secreted frizzled-related protein-1 and frizzled 4- and frizzled 7-dependent pathway: role in neovessel formation. Am. J. Pathol. 172: 37-49 [PMID:18156211]

30. Endo Y, Beauchamp E, Woods D, Taylor WG, Toretsky JA, Uren A and Rubin JS. (2008) Wnt-3a and Dickkopf-1 stimulate neurite outgrowth in Ewing tumor cells via a Frizzled3- and c-Jun N-terminal kinasedependent mechanism. Mol. Cell. Biol. 28: 2368-79 [PMID:18212053]

31. Favre CJ, Mancuso M, Maas K, McLean JW, Baluk P and McDonald DM. (2003) Expression of genes involved in vascular development and angiogenesis in endothelial cells of adult lung. Am. J. Physiol. Heart Circ. Physiol. 285: H1917-38 [PMID:12842817]

32. Fischer T, Guimera J, Wurst W and Prakash N. (2007) Distinct but redundant expression of the Frizzled Wnt receptor genes at signaling centers of the developing mouse brain. Neuroscience 147: 693-711 [PMID:17582687]

33. Foord SM, Bonner TI, Neubig RR, Rosser EM, Pin JP, Davenport AP, Spedding M and Harmar AJ. (2005) International Union of Pharmacology. XLVI. G protein-coupled receptor list. Pharmacol. Rev. 57: 279-88 [PMID:15914470]

34. Fröjmark AS, Schuster J, Sobol M, Entesarian M, Kilander MB, Gabrikova D, Nawaz S, Baig SM, Schulte $G$ and Klar J et al.. (2011) Mutations in frizzled 6 cause isolated autosomal-recessive nail dysplasia.Am. J. Hum. Genet. 88: 852-60 [PMID:21665003]

35. Fujimoto T, Tomizawa M and Yokosuka O. (2009) SiRNA of frizzled-9 suppresses proliferation and motility of hepatoma cells. Int. J. Oncol. 35: 861-6 [PMID:19724923]

36. Fukukawa C, Nagayama S, Tsunoda T, Toguchida J, Nakamura $Y$ and Katagiri T. (2009) Activation of the non-canonical Dvl-Rac1-JNK pathway by Frizzled homologue 10 in human synovial sarcoma. Oncogene 28: 1110-20 [PMID:19137009]

37. Gao Y and Wang HY. (2006) Casein kinase 2 Is activated and essential for Wnt/beta-catenin signaling.J. Biol. Chem. 281: 18394-400 [PMID:16672224]

38. Gao Y and Wang HY. (2007) Inositol pentakisphosphate mediates Wnt/beta-catenin signaling.J. Biol. Chem. 282: 26490-502 [PMID:17595165]

39. Gazit A, Yaniv A, Bafico A, Pramila T, Igarashi M, Kitajewski J and Aaronson SA. (1999) Human frizzled 1 interacts with transforming Wnts to transduce a TCF dependent transcriptional response. Oncogene 18: 5959-66 [PMID:10557084]

40. Gitter KA, Rothschild H, Waltman DD, Scott B and Azar P. (1978) Dominantly inherited peripheral retinal neovascularization. Arch. Ophthalmol. 96: 1601-5 [PMID:687201]

41. Golan T, Yaniv A, Bafico A, Liu G and Gazit A. (2004) The human Frizzled 6 (HFz6) acts as a negative regulator of the canonical Wnt. beta-catenin signaling cascade. J. Biol. Chem. 279: 14879-88 [PMID:14747478]

42. Gordon MD and Nusse R. (2006) Wnt signaling: multiple pathways, multiple receptors, and multiple transcription factors. J Biol Chem 281: 22429-22433 [PMID:16793760]

43. Gow J and Oliver GL. (1971) Familial exudative vitreoretinopathy. An expanded view.Arch. Ophthalmol. 
86: 150-5 [PMID:5571414]

44. Gregorieff A, Pinto D, Begthel H, Destrée O, Kielman M and Clevers H. (2005) Expression pattern of Wnt signaling components in the adult intestine. Gastroenterology 129: 626-38 [PMID:16083717]

45. Gregory MA, Phang TL, Neviani P, Alvarez-Calderon F, Eide CA, O'Hare T, Zaberezhnyy V, Williams RT, Druker BJ and Perrotti D et al.. (2010) Wnt/Ca2+/NFAT signaling maintains survival of $\mathrm{Ph}$ + leukemia cells upon inhibition of Bcr-Abl. Cancer Cell 18: 74-87 [PMID:20609354]

46. Guo N, Hawkins $C$ and Nathans J. (2004) Frizzled6 controls hair patterning in mice Proc. Natl. Acad. Sci. U.S.A. 101: 9277-81 [PMID:15169958]

47. Gurney A, Axelrod F, Bond CJ, Cain J, Chartier C, Donigan L, Fischer M, Chaudhari A, Ji M and Kapoun AM et al.. (2012) Wnt pathway inhibition via the targeting of Frizzled receptors results in decreased growth and tumorigenicity of human tumors. Proc. Natl. Acad. Sci. U.S.A. 109: 11717-22 [PMID:22753465]

48. Hansen C, Howlin J, Tengholm A, Dyachok O, Vogel WF, Nairn AC, Greengard P and Andersson T. (2009) Wnt-5a-induced phosphorylation of DARPP-32 inhibits breast cancer cell migration in a CREBdependent manner. J. Biol. Chem. 284: 27533-43 [PMID:19651774]

49. Heinonen KM, Vanegas JR, Lew D, Krosl J and Perreault C. (2011) Wnt4 enhances murine hematopoietic progenitor cell expansion through a planar cell polarity-like pathway. PLOS ONE 6: e19279 [PMID:21541287]

50. Hendrickx M and Leyns L. (2008) Non-conventional Frizzled ligands and Wnt receptors.Dev. Growth Differ. 50: 229-43 [PMID:18366384]

51. Holcombe RF, Marsh JL, Waterman ML, Lin F, Milovanovic T and Truong T. (2002) Expression of Wnt ligands and Frizzled receptors in colonic mucosa and in colon carcinoma. MP, Mol. Pathol. 55: 220-6 [PMID:12147710]

52. Hot B, Valnohova J, Arthofer E, Simon K, Shin J, Uhlén M, Kostenis E, Mulder J and Schulte G. (2017) FZD10-G $\alpha 13$ signalling axis points to a role of FZD10 in CNS angiogenesis. Cell. Signal. 32: 93-103 [PMID:28126591]

53. Hsieh JC, Rattner A, Smallwood PM and Nathans J. (1999) Biochemical characterization of Wnt-frizzled interactions using a soluble, biologically active vertebrate Wnt protein. Proc. Natl. Acad. Sci. U.S.A. 96: 3546-51 [PMID:10097073]

54. Hsieh M, Boerboom D, Shimada M, Lo Y, Parlow AF, Luhmann UF, Berger W and Richards JS. (2005) Mice null for Frizzled4 (Fzd4-/-) are infertile and exhibit impaired corpora lutea formation and function. Biol. Reprod. 73: 1135-46 [PMID:16093361]

55. Huang P, Zheng S, Wierbowski BM, Kim Y, Nedelcu D, Aravena L, Liu J, Kruse AC and Salic A. (2018) Structural Basis of Smoothened Activation in Hedgehog Signaling. Cell 174: 312-324.e16 [PMID:29804838]

56. Hughes KR, Sablitzky F and Mahida YR. (2011) Expression profiling of Wnt family of genes in normal and inflammatory bowel disease primary human intestinal myofibroblasts and normal human colonic crypt epithelial cells. Inflamm. Bowel Dis. 17: 213-20 [PMID:20848536]

57. Ide M, Muratake T, Yamada K, Iwayama-Shigeno Y, Iwamoto K, Takao H, Toyota T, Kaneko N, Minabe Y and Nakamura K et al.. (2004) Genetic and expression analyses of FZD3 in schizophrenia.Biol. Psychiatry 56: 462-5 [PMID:15364045]

58. Inestrosa NC and Arenas E. (2010) Emerging roles of Wnts in the adult nervous systemNat. Rev. Neurosci. 11: 77-86 [PMID:20010950]

59. Ishikawa T, Tamai Y, Zorn AM, Yoshida H, Seldin MF, Nishikawa S and Taketo MM. (2001) Mouse Wnt receptor gene Fzd5 is essential for yolk sac and placental angiogenesis. Development 128: 25-33 [PMID:11092808]

60. Janda CY, Waghray D, Levin AM, Thomas C and Garcia KC. (2012) Structural basis of Wnt recognition by Frizzled. Science 337: 59-64 [PMID:22653731]

61. Janssens N, Andries L, Janicot M, Perera T and Bakker A. (2004) Alteration of frizzled expression in renal cell carcinoma. Tumour Biol. 25: 161-71 [PMID:15557753]

62. Jenei V, Sherwood V, Howlin J, Linnskog R, Säfholm A, Axelsson L and Andersson T. (2009) A t- 
butyloxycarbonyl-modified Wnt5a-derived hexapeptide functions as a potent antagonist of Wnt5adependent melanoma cell invasion. Proc. Natl. Acad. Sci. U.S.A. 106: 19473-8 [PMID:19901340]

63. Jiang Y, Dunbar A, Gondek LP, Mohan S, Rataul M, O'Keefe C, Sekeres M, Saunthararajah Y and Maciejewski JP. (2009) Aberrant DNA methylation is a dominant mechanism in MDS progression to AML. Blood 113: 1315-25 [PMID:18832655]

64. Kang G, Yue W, Zhang J, Huebner M, Zhang H, Ruan Y, Lu T, Ling Y, Zuo Y and Zhang D. (2008) Twostage designs to identify the effects of SNP combinations on complex diseases. J. Hum. Genet. 53: 739-46 [PMID:18584117]

65. Karasawa T, Yokokura H, Kitajewski J and Lombroso PJ. (2002) Frizzled-9 is activated by Wnt-2 and functions in Wnt/beta -catenin signaling. J. Biol. Chem. 277: 37479-86 [PMID:12138115]

66. Kasai K, Takahashi M, Osumi N, Sinnarajah S, Takeo T, Ikeda H, Kehrl JH, Itoh G and Arnheiter H. (2004) The $\mathrm{G} 12$ family of heterotrimeric $\mathrm{G}$ proteins and Rho GTPase mediate Sonic hedgehog signalling. Genes Cells 9: 49-58 [PMID:14723707]

67. Katanaev VL and Buestorf S. Frizzled Proteins are bona fide G Protein-Coupled Receptors.

68. Katsu T, Ujike H, Nakano T, Tanaka Y, Nomura A, Nakata K, Takaki M, Sakai A, Uchida N and Imamura T et al.. (2003) The human frizzled-3 (FZD3) gene on chromosome 8p21, a receptor gene for Wnt ligands, is associated with the susceptibility to schizophrenia. Neurosci. Lett. 353: 53-6 [PMID:14642436]

69. Kaucká M, Plevová K, Pavlová S, Janovská P, Mishra A, Verner J, Procházková J, Krejcí P, Kotasková J and Ovesná $\mathrm{P}$ et al.. (2013) The planar cell polarity pathway drives pathogenesis of chronic lymphocytic leukemia by the regulation of B-lymphocyte migration. Cancer Res. 73: 1491-501 [PMID:23338609]

70. Kawasaki A, Torii K, Yamashita Y, Nishizawa K, Kanekura K, Katada M, Ito M, Nishimoto I, Terashita K and Aiso $S$ et al.. (2007) Wnt5a promotes adhesion of human dermal fibroblasts by triggering a phosphatidylinositol-3 kinase/Akt signal. Cell. Signal. 19: 2498-506 [PMID:17804197]

71. Kaykas A, Yang-Snyder J, Héroux M, Shah KV, Bouvier M and Moon RT. (2004) Mutant Frizzled 4 associated with vitreoretinopathy traps wild-type Frizzled in the endoplasmic reticulum by oligomerization. Nat Cell Biol 6: 52-58 [PMID:14688793]

72. Keay SK, Szekely Z, Conrads TP, Veenstra TD, Barchi Jr JJ, Zhang CO, Koch KR and Michejda CJ. (2004) An antiproliferative factor from interstitial cystitis patients is a frizzled 8 protein-related sialoglycopeptide. Proc. Natl. Acad. Sci. U.S.A. 101: 11803-8 [PMID:15282374]

73. Kemp CR, Willems E, Wawrzak D, Hendrickx M, Agbor Agbor T and Leyns L. (2007) Expression of Frizzled5, Frizzled7, and Frizzled10 during early mouse development and interactions with canonical Wnt signaling. Dev. Dyn. 236: 2011-9 [PMID:17576136]

74. Khan NI, Bradstock KF and Bendall LJ. (2007) Activation of Wnt/beta-catenin pathway mediates growth and survival in B-cell progenitor acute lymphoblastic leukaemia. Br. J. Haematol. 138: 338-48 [PMID:17614820]

75. Kikuchi A, Yamamoto $H$ and Kishida S. (2007) Multiplicity of the interactions of Wnt proteins and their receptors. Cell. Signal. 19: 659-71 [PMID:17188462]

76. Kikuchi A, Yamamoto $\mathrm{H}$ and Sato A. (2009) Selective activation mechanisms of Wnt signaling pathways. Trends Cell Biol. 19: 119-29 [PMID:19208479]

77. Kilander MB, Dahlström J and Schulte G. (2014) Assessment of Frizzled 6 membrane mobility by FRAP supports $G$ protein coupling and reveals WNT-Frizzled selectivity. Cell. Signal. 26: 1943-9 [PMID:24873871]

78. Kilander MB, Dijksterhuis JP, Ganji RS, Bryja V and Schulte G. (2011) WNT-5A stimulates the GDP/GTP exchange at pertussis toxin-sensitive heterotrimeric G proteins. Cell. Signal. 23: 550-4 [PMID:21070854]

79. Kilander MB, Petersen J, Andressen KW, Ganji RS, Levy FO, Schuster J, Dahl N, Bryja V and Schulte G. (2014) Disheveled regulates precoupling of heterotrimeric G proteins to Frizzled 6. FASEB J. 28: 2293-305 [PMID:24500924]

80. Kim GH and Han JK. (2007) Essential role for beta-arrestin 2 in the regulation of Xenopus convergent extension movements. EMBO J. 26: 2513-26 [PMID:17476309]

81. Kim M, Lee HC, Tsedensodnom O, Hartley R, Lim YS, Yu E, Merle P and Wands JR. (2008) Functional 
interaction between Wnt3 and Frizzled-7 leads to activation of the Wnt/beta-catenin signaling pathway in hepatocellular carcinoma cells. J. Hepatol. 48: 780-91 [PMID:18313787]

82. King TD, Zhang W, Suto MJ and Li Y. (2012) Frizzled7 as an emerging target for cancer therapy.Cell. Signal. 24: 846-51 [PMID:22182510]

83. Kirikoshi H, Koike J, Sagara N, Saitoh T, Tokuhara M, Tanaka K, Sekihara H, Hirai M and Katoh M. (2000) Molecular cloning and genomic structure of human frizzled-3 at chromosome 8p21. Biochem. Biophys. Res. Commun. 271: 8-14 [PMID:10777673]

84. Kirikoshi H, Sagara N, Koike J, Tanaka K, Sekihara H, Hirai M and Katoh M. (1999) Molecular cloning and characterization of human Frizzled-4 on chromosome 11q14-q21. Biochem. Biophys. Res. Commun. 264: 955-61 [PMID:10544037]

85. Kirikoshi $H$, Sekihara $H$ and Katoh M. (2001) Up-regulation of Frizzled-7 (FZD7) in human gastric cancer. Int. J. Oncol. 19: 111-5 [PMID:11408930]

86. Klein D, Demory A, Peyre F, Kroll J, Augustin HG, Helfrich W, Kzhyshkowska J, Schledzewski K, Arnold B and Goerdt S. (2008) Wnt2 acts as a cell type-specific, autocrine growth factor in rat hepatic sinusoidal endothelial cells cross-stimulating the VEGF pathway. Hepatology 47: 1018-31 [PMID:18302287]

87. Kolben T, Peröbner I, Fernsebner K, Lechner F, Geissler C, Ruiz-Heinrich L, Capovilla S, Jochum M and Neth P. (2012) Dissecting the impact of Frizzled receptors in Wnt/ $\beta$-catenin signaling of human mesenchymal stem cells. Biol. Chem. 393: 1433-47 [PMID:23152409]

88. Kondo H, Hayashi H, Oshima K, Tahira T and Hayashi K. (2003) Frizzled 4 gene (FZD4) mutations in patients with familial exudative vitreoretinopathy with variable expressivity. $\mathrm{Br} J$ Ophthalmol 87: 1291-5 [PMID:14507768]

89. Kondo H, Qin M, Tahira T, Uchio E and Hayashi K. (2007) Severe form of familial exudative vitreoretinopathy caused by homozygous R417Q mutation in frizzled-4 gene. Ophthalmic Genet. 28: 220-3 [PMID:18161623]

90. Koval A and Katanaev VL. (2011) Wnt3a stimulation elicits G-protein-coupled receptor properties of mammalian Frizzled proteins. Biochem. J. 433: 435-40 [PMID:21128903]

91. Koval A, Purvanov V, Egger-Adam D and Katanaev VL. (2011) Yellow submarine of the Wnt/Frizzled signaling: submerging from the G protein harbor to the targets. Biochem. Pharmacol. 82: 1311-9 [PMID:21689640]

92. Kumar S, Zigman M, Patel TR, Trageser B, Gross JC, Rahm K, Boutros M, Gradl D, Steinbeisser H and Holstein T et al.. (2014) Molecular dissection of Wnt3a-Frizzled8 interaction reveals essential and modulatory determinants of Wnt signaling activity. BMC Biol. 12: 44 [PMID:24885675]

93. Laeremans H, Hackeng TM, van Zandvoort MA, Thijssen VL, Janssen BJ, Ottenheijm HC, Smits JF and Blankesteijn WM. (2011) Blocking of frizzled signaling with a homologous peptide fragment of wnt3a/wnt5a reduces infarct expansion and prevents the development of heart failure after myocardial infarction.

Circulation 124: 1626-35 [PMID:21931076]

94. Lapointe E, Boyer A, Rico C, Paquet M, Franco HL, Gossen J, DeMayo FJ, Richards JS and Boerboom D. (2012) FZD1 regulates cumulus expansion genes and is required for normal female fertility in mice. Biol. Reprod. 87: 104 [PMID:22954793]

95. Le Grand F, Jones AE, Seale V, Scimè A and Rudnicki MA. (2009) Wnt7a activates the planar cell polarity pathway to drive the symmetric expansion of satellite stem cells. Cell Stem Cell 4: 535-47 [PMID:19497282]

96. Li B, Zhong L, Yang X, Andersson T, Huang M and Tang SJ. (2011) WNT5A signaling contributes to A induced neuroinflammation and neurotoxicity. PLOS ONE 6: e22920 [PMID:21857966]

97. Liu C, Wang Y, Smallwood PM and Nathans J. (2008) An essential role for Frizzled5 in neuronal survival in the parafascicular nucleus of the thalamus. J. Neurosci. 28: 5641-53 [PMID:18509025]

98. Liu T, Liu X, Wang Hy, Moon RT and Malbon CC. (1999) Activation of rat frizzled-1 promotes Wnt signaling and differentiation of mouse $\mathrm{F} 9$ teratocarcinoma cells via pathways that require Galpha(q) and Galpha(o) function. J. Biol. Chem. 274: 33539-44 [PMID:10559239]

99. Lu D, Zhao Y, Tawatao R, Cottam HB, Sen M, Leoni LM, Kipps TJ, Corr M and Carson DA. (2004) 
Activation of the Wnt signaling pathway in chronic lymphocytic leukemia. Proc. Natl. Acad. Sci. U.S.A. 101: 3118-23 [PMID:14973184]

100. Lu J, Zhang S, Nakano H, Simmons DG, Wang S, Kong S, Wang Q, Shen L, Tu Z and Wang Wet al.. (2013) A positive feedback loop involving Gcm1 and Fzd5 directs chorionic branching morphogenesis in the placenta. PLoS Biol. 11: e1001536 [PMID:23610556]

101. Luchetti G, Sircar R, Kong JH, Nachtergaele S, Sagner A, Byrne EF, Covey DF, Siebold C and Rohatgi R. (2016) Cholesterol activates the G-protein coupled receptor Smoothened to promote Hedgehog signaling.

Elife 5: [PMID:27705744]

102. Luhmann UF, Neidhardt J, Kloeckener-Gruissem B, Schäfer NF, Glaus E, Feil S and Berger W. (2008) Vascular changes in the cerebellum of Norrin /Ndph knockout mice correlate with high expression of Norrin and Frizzled-4. Eur. J. Neurosci. 27: 2619-28 [PMID:18547247]

103. Lum L and Beachy PA. (2004) The Hedgehog response network: sensors, switches, and routers.Science 304: 1755-9 [PMID:15205520]

104. Luo J, Chen J, Deng ZL, Luo X, Song WX, Sharff KA, Tang N, Haydon RC, Luu HH and He TC. (2007) Wnt signaling and human diseases: what are the therapeutic implications? Lab. Invest. 87: 97-103 [PMID:17211410]

105. Lyons JP, Mueller UW, Ji H, Everett C, Fang X, Hsieh JC, Barth AM and McCrea PD. (2004) Wnt-4 activates the canonical beta-catenin-mediated Wnt pathway and binds Frizzled-6 CRD: functional implications of Wnt/beta-catenin activity in kidney epithelial cells. Exp. Cell Res. 298: 369-87 [PMID:15265686]

106. Lyuksyutova AI, Lu CC, Milanesio N, King LA, Guo N, Wang Y, Nathans J, Tessier-Lavigne M and Zou Y. (2003) Anterior-posterior guidance of commissural axons by Wnt-frizzled signaling. Science 302: 1984-8 [PMID:14671310]

107. Ma L and Wang HY. (2006) Suppression of cyclic GMP-dependent protein kinase is essential to the Wnt/cGMP/Ca2+ pathway. J. Biol. Chem. 281: 30990-1001 [PMID:16920709]

108. Ma L and Wang HY. (2007) Mitogen-activated protein kinase p38 regulates the Wnt/cyclic GMP/Ca2+ noncanonical pathway. J. Biol. Chem. 282: 28980-90 [PMID:17684012]

109. MacDonald BT and He X. (2012) Frizzled and LRP5/6 receptors for Wnt/3-catenin signaling.Cold Spring Harb Perspect Biol 4: [PMID:23209147]

110. MacDonald BT, Tamai $\mathrm{K}$ and He X. (2009) Wnt/beta-catenin signaling: components, mechanisms, and diseases. Dev. Cell 17: 9-26 [PMID:19619488]

111. MacDonald ML, Goldberg YP, Macfarlane J, Samuels ME, Trese MT and Shastry BS. (2005) Genetic variants of frizzled-4 gene in familial exudative vitreoretinopathy and advanced retinopathy of prematurity. Clin. Genet. 67: 363-6 [PMID:15733276]

112. Magdesian MH, Carvalho MM, Mendes FA, Saraiva LM, Juliano MA, Juliano L, Garcia-Abreu J and Ferreira ST. (2008) Amyloid-beta binds to the extracellular cysteine-rich domain of Frizzled and inhibits Wnt/beta-catenin signaling. J. Biol. Chem. 283: 9359-68 [PMID:18234671]

113. Malaterre J, Ramsay RG and Mantamadiotis T. (2007) Wnt-Frizzled signalling and the many paths to neural development and adult brain homeostasis. Front Biosci 12: 492-506 [PMID:17127312]

114. Malik TH and Shivdasani RA. (2000) Structure and expression of a novel frizzled gene isolated from the developing mouse gut. Biochem. J. 349 Pt 3: 829-34 [PMID:10903145]

115. Manning DR, Shen F and Riobo NA. (2015) Evaluating the Activity of Smoothened Toward G Proteins Using [ ${ }^{5} S$ S]Guanosine 5'-(3-O-thio)triphosphate ([†5S]GTPYS). Methods Mol. Biol. 1322: 35-44 [PMID:26179037]

116. Mao J, Ligon KL, Rakhlin EY, Thayer SP, Bronson RT, Rowitch D and McMahon AP. (2006) A novel somatic mouse model to survey tumorigenic potential applied to the Hedgehog pathway. Cancer Res. 66: 10171-8 [PMID:17047082]

117. Masckauchán TN, Shawber CJ, Funahashi Y, Li CM and Kitajewski J. (2005) Wnt/beta-catenin signaling induces proliferation, survival and interleukin-8 in human endothelial cells. Angiogenesis 8: 43-51 [PMID:16132617] 
118. Masdeu C, Faure H, Coulombe J, Schoenfelder A, Mann A, Brabet I, Pin JP, Traiffort E and Ruat M. (2006) Identification and characterization of Hedgehog modulator properties after functional coupling of Smoothened to G15. Biochem. Biophys. Res. Commun. 349: 471-9 [PMID:16945339]

119. Meloni AR, Fralish GB, Kelly P, Salahpour A, Chen JK, Wechsler-Reya RJ, Lefkowitz RJ and Caron MG. (2006) Smoothened signal transduction is promoted by G protein-coupled receptor kinase 2. Mol. Cell. Biol. 26: 7550-60 [PMID:16908539]

120. Merle P, de la Monte S, Kim M, Herrmann M, Tanaka S, Von Dem Bussche A, Kew MC, Trepo C and Wands JR. (2004) Functional consequences of frizzled-7 receptor overexpression in human hepatocellular carcinoma. Gastroenterology 127: 1110-22 [PMID:15480989]

121. Mikels AJ and Nusse R. (2006) Purified Wnt5a protein activates or inhibits beta-catenin-TCF signaling depending on receptor context. PLoS Biol. 4: e115 [PMID:16602827]

122. Miyakoshi T, Takei M, Kajiya H, Egashira N, Takekoshi S, Teramoto A and Osamura RY. (2008) Expression of Wnt4 in human pituitary adenomas regulates activation of the beta-catenin-independent pathway. Endocr. Pathol. 19: 261-73 [PMID:19034702]

123. Montcouquiol M, Sans N, Huss D, Kach J, Dickman JD, Forge A, Rachel RA, Copeland NG, Jenkins NA and Bogani $D$ et al.. (2006) Asymmetric localization of Vangl2 and Fz3 indicate novel mechanisms for planar cell polarity in mammals. J. Neurosci. 26: 5265-75 [PMID:16687519]

124. Munchhof MJ, Li Q, Shavnya A, Borzillo GV, Boyden TL, Jones CS, LaGreca SD, Martinez-Alsina L, Patel $\mathrm{N}$ and Pelletier K et al.. (2012) Discovery of PF-04449913, a Potent and Orally Bioavailable Inhibitor of Smoothened. ACS Med Chem Lett 3: 106-11 [PMID:24900436]

125. Nagayama S, Fukukawa C, Katagiri T, Okamoto T, Aoyama T, Oyaizu N, Imamura M, Toguchida J and Nakamura Y. (2005) Therapeutic potential of antibodies against FZD 10, a cell-surface protein, for synovial sarcomas. Oncogene 24: 6201-12 [PMID:16007199]

126. Naz G, Pasternack SM, Perrin C, Mattheisen M, Refke M, Khan S, Gul A, Simons M, Ahmad W and Betz RC. (2012) FZD6 encoding the Wnt receptor frizzled 6 is mutated in autosomal-recessive nail dysplasia. Br. J. Dermatol. 166: 1088-94 [PMID:22211385]

127. Neumann J, Schaale K, Farhat K, Endermann T, Ulmer AJ, Ehlers S and Reiling N. (2010) Frizzled1 is a marker of inflammatory macrophages, and its ligand Wnt3a is involved in reprogramming Mycobacterium tuberculosis-infected macrophages. FASEB J. 24: 4599-612 [PMID:20667980]

128. Nusse R. (2003) Wnts and Hedgehogs: lipid-modified proteins and similarities in signaling mechanisms at the cell surface. Development 130: 5297-305 [PMID:14530294]

129. Nusse R. (2005) Wnt signaling in disease and in development.Cell Res. 15: 28-32 [PMID:15686623]

130. Ogden SK, Ascano Jr M, Stegman MA and Robbins DJ. (2004) Regulation of Hedgehog signaling: a complex story. Biochem. Pharmacol. 67: 805-14 [PMID:15104233]

131. Ogden SK, Fei DL, Schilling NS, Ahmed YF, Hwa J and Robbins DJ. (2008) G protein Galphai functions immediately downstream of Smoothened in Hedgehog signalling. Nature 456: 967-70 [PMID:18987629]

132. Ohashi T, Oguro $Y$, Tanaka T, Shiokawa Z, Tanaka $Y$, Shibata S, Sato $Y$, Yamakawa H, Hattori $H$ and Yamamoto $Y$ et al.. (2012) Discovery of the investigational drug TAK-441, a pyrrolo[3,2-c]pyridine derivative, as a highly potent and orally active hedgehog signaling inhibitor: modification of the core skeleton for improved solubility. Bioorg. Med. Chem. 20: 5507-17 [PMID:22898254]

133. Pan W, Choi SC, Wang H, Qin Y, Volpicelli-Daley L, Swan L, Lucast L, Khoo C, Zhang X and Li let al.. (2008) Wnt3a-mediated formation of phosphatidylinositol 4,5-bisphosphate regulates LRP6 phosphorylation. Science 321: 1350-3 [PMID:18772438]

134. Papadopoulou $S$ and Edlund H. (2005) Attenuated Wnt signaling perturbs pancreatic growth but not pancreatic function. Diabetes 54: 2844-51 [PMID:16186384]

135. Petersen J, Wright SC, Rodríguez D, Matricon P, Lahav N, Vromen A, Friedler A, Strömqvist J, Wennmalm S and Carlsson J et al.. (2017) Agonist-induced dimer dissociation as a macromolecular step in G protein-coupled receptor signaling. Nat Commun 8: 226 [PMID:28790300]

136. Planutis K, Planutiene M, Moyer MP, Nguyen AV, Pérez CA and Holcombe RF. (2007) Regulation of norrin receptor frizzled-4 by Wnt2 in colon-derived cells. BMC Cell Biol. 8: 12 [PMID:17386109] 
137. Povelones M and Nusse R. (2005) The role of the cysteine-rich domain of Frizzled in Wingless-Armadillo signaling. EMBO J. 24: 3493-503 [PMID:16163385]

138. Qin M, Hayashi H, Oshima K, Tahira T, Hayashi K and Kondo H. (2005) Complexity of the genotypephenotype correlation in familial exudative vitreoretinopathy with mutations in the LRP5 and/or FZD4 genes. Hum. Mutat. 26: 104-12 [PMID:15981244]

139. Raleigh DR, Sever N, Choksi PK, Sigg MA, Hines KM, Thompson BM, Elnatan D, Jaishankar P, Bisignano P and Garcia-Gonzalo FR et al.. (2018) Cilia-Associated Oxysterols Activate Smoothened.Mol. Cell 72: 316-327.e5 [PMID:30340023]

140. Ramírez VT, Ramos-Fernández E, Henríquez JP, Lorenzo A and Inestrosa NC. (2016) Wnt-5a/Frizzled9

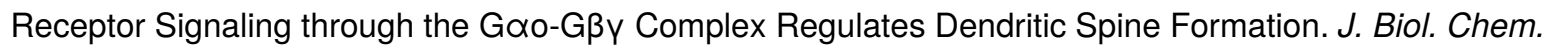
291: 19092-107 [PMID:27402827]

141. Ranchod TM, Ho LY, Drenser KA, Capone Jr A and Trese MT. (2011) Clinical presentation of familial exudative vitreoretinopathy. Ophthalmology 118: 2070-5 [PMID:21868098]

142. Ranheim EA, Kwan HC, Reya T, Wang YK, Weissman IL and Francke U. (2005) Frizzled 9 knock-out mice have abnormal B-cell development. Blood 105: 2487-94 [PMID:15572594]

143. Rawal N, Castelo-Branco G, Sousa KM, Kele J, Kobayashi K, Okano H and Arenas E. (2006) Dynamic temporal and cell type-specific expression of Wnt signaling components in the developing midbrain. Exp. Cell Res. 312: 1626-36 [PMID:16510140]

144. Raza SI, Muhammad N, Khan S and Ahmad W. (2013) A novel missense mutation in the gene FZD6 underlies autosomal recessive nail dysplasia. Br. J. Dermatol. 168: 422-5 [PMID:22861124]

145. Regard JB, Sato IT and Coughlin SR. (2008) Anatomical profiling of G protein-coupled receptor expression. Cell 135: 561-71 [PMID:18984166]

146. Riobo NA and Manning DR. (2007) Pathways of signal transduction employed by vertebrate Hedgehogs. Biochem J 403: 369-379 [PMID:17419683]

147. Riobo NA, Saucy B, Dilizio $C$ and Manning DR. (2006) Activation of heterotrimeric G proteins by Smoothened. Proc. Natl. Acad. Sci. U.S.A. 103: 12607-12 [PMID:16885213]

148. Robitaille J, MacDonald ML, Kaykas A, Sheldahl LC, Zeisler J, Dubé MP, Zhang LH, Singaraja RR, Guernsey DL, Zheng B, Siebert LF, Hoskin-Mott A, Trese MT, Pimstone SN, Shastry BS, Moon RT, Hayden MR, Goldberg YP and Samuels ME. (2002) Mutant frizzled-4 disrupts retinal angiogenesis in familial exudative vitreoretinopathy. Nat Genet 32: 326-330 [PMID:12172548]

149. Sagara N, Toda G, Hirai M, Terada M and Katoh M. (1998) Molecular cloning, differential expression, and chromosomal localization of human frizzled-1, frizzled-2, and frizzled-7. Biochem. Biophys. Res. Commun. 252: 117-22 [PMID:9813155]

150. Sahores M, Gibb A and Salinas PC. (2010) Frizzled-5, a receptor for the synaptic organizer Wnt7a, regulates activity-mediated synaptogenesis. Development 137: 2215-25 [PMID:20530549]

151. Saitoh T, Hirai M and Katoh M. (2001) Molecular cloning and characterization of human Frizzled-5 gene on chromosome 2q33.3-q34 region. Int. J. Oncol. 19: 105-10 [PMID:11408929]

152. Saitoh T, Hirai M and Katoh M. (2001) Molecular cloning and characterization of human Frizzled-8 gene on chromosome 10p11.2. Int. J. Oncol. 18: 991-6 [PMID:11295046]

153. Sala CF, Formenti E, Terstappen GC and Caricasole A. (2000) Identification, gene structure, and expression of human frizzled-3 (FZD3). Biochem. Biophys. Res. Commun. 273: 27-34 [PMID:10873558]

154. Salsano E, Paterra R, Figus M, Menghi F, Maderna E, Pollo B, Solero CL, Massimi L and Finocchiaro G. (2012) Expression profile of frizzled receptors in human medulloblastomas. J. Neurooncol. 106: 271-80 [PMID:21850537]

155. Sammeta N, Yu TT, Bose SC and McClintock TS. (2007) Mouse olfactory sensory neurons express 10,000 genes. J. Comp. Neurol. 502: 1138-56 [PMID:17444493]

156. Schulte G. (2010) International Union of Basic and Clinical Pharmacology. LXXX. The class Frizzled receptors. Pharmacol. Rev. 62: 632-67 [PMID:21079039]

157. Schulte G and Bryja V. (2007) The Frizzled family of unconventional G-protein-coupled receptors.Trends Pharmacol. Sci. 28: 518-25 [PMID:17884187] 
158. Schulte G, Bryja V, Rawal N, Castelo-Branco G, Sousa KM and Arenas E. (2005) Purified Wnt-5a increases differentiation of midbrain dopaminergic cells and dishevelled phosphorylation. J. Neurochem. 92: 1550-3 [PMID:15748172]

159. Schulte G and Wright SC. (2018) Frizzleds as GPCRs - More Conventional Than We Thought:Trends Pharmacol. Sci. 39: 828-842 [PMID:30049420]

160. Sen M, Lauterbach K, El-Gabalawy H, Firestein GS, Corr M and Carson DA. (2000) Expression and function of wingless and frizzled homologs in rheumatoid arthritis. Proc. Natl. Acad. Sci. U.S.A. 97: 2791-6 [PMID:10688908]

161. Shastry BS. (2009) Persistent hyperplastic primary vitreous: congenital malformation of the eye.Clin. Experiment. Ophthalmol. 37: 884-90 [PMID:20092598]

162. Shen F, Cheng L, Douglas AE, Riobo NA and Manning DR. (2013) Smoothened is a fully competent activator of the heterotrimeric $\mathrm{G}$ protein $\mathrm{G}(\mathrm{i})$. Mol. Pharmacol. 83: 691-7 [PMID:23292797]

163. Shen G, Ke J, Wang Z, Cheng Z, Gu X, Wei Y, Melcher K, Xu HE and Xu W. (2015) Structural basis of the Norrin-Frizzled 4 interaction. Cell Res. 25: 1078-81 [PMID:26227961]

164. Slusarski DC, Corces VG and Moon RT. (1997) Interaction of Wnt and a Frizzled homologue triggers Gprotein-linked phosphatidylinositol signalling. Nature 390: 410-3 [PMID:9389482]

165. Slusher MM and Hutton WE. (1979) Familial exudative vitreoretinopathy.Am. J. Ophthalmol. 87: 152-6 [PMID:434067]

166. Sonnet M, Claus R, Becker N, Zucknick M, Petersen J, Lipka DB, Oakes CC, Andrulis M, Lier A and Milsom MD et al.. (2014) Early aberrant DNA methylation events in a mouse model of acute myeloid leukemia. Genome Med 6: 34 [PMID:24944583]

167. Stenson PD, Ball EV, Mort M, Phillips AD, Shiel JA, Thomas NS, Abeysinghe S, Krawczak M and Cooper DN. (2003) Human Gene Mutation Database (HGMD): 2003 update. Hum. Mutat. 21: 577-81 [PMID:12754702]

168. Stone DM, Hynes M, Armanini M, Swanson TA, Gu Q, Johnson RL, Scott MP, Pennica D, Goddard A and Phillips $\mathrm{H}$ et al.. (1996) The tumour-suppressor gene patched encodes a candidate receptor for Sonic hedgehog. Nature 384: 129-34 [PMID:8906787]

169. Stuebner S, Faus-Kessler T, Fischer T, Wurst W and Prakash N. (2010) Fzd3 and Fzd6 deficiency results in a severe midbrain morphogenesis defect. Dev. Dyn. 239: 246-60 [PMID:19842188]

170. Su AI, Wiltshire T, Batalov S, Lapp H, Ching KA, Block D, Zhang J, Soden R, Hayakawa M and Kreiman G et al.. (2004) A gene atlas of the mouse and human protein-encoding transcriptomes.Proc. Natl. Acad. Sci. U.S.A. 101: 6062-7 [PMID:15075390]

171. Sugimura R, He XC, Venkatraman A, Arai F, Box A, Semerad C, Haug JS, Peng L, Zhong XB and Suda T et al.. (2012) Noncanonical Wnt signaling maintains hematopoietic stem cells in the niche.Cell 150: 351-65 [PMID:22817897]

172. Summerhurst K, Stark M, Sharpe J, Davidson D and Murphy P. (2008) 3D representation of Wnt and Frizzled gene expression patterns in the mouse embryo at embryonic day 11.5 (Ts19). Gene Expr. Patterns 8: 331-48 [PMID:18364260]

173. Säfholm A, Tuomela J, Rosenkvist J, Dejmek J, Härkönen P and Andersson T. (2008) The Wnt-5a-derived hexapeptide Foxy-5 inhibits breast cancer metastasis in vivo by targeting cell motility. Clin. Cancer Res. 14: 6556-63 [PMID:18927296]

174. Taipale J, Chen JK, Cooper MK, Wang B, Mann RK, Milenkovic L, Scott MP and Beachy PA. (2000) Effects of oncogenic mutations in Smoothened and Patched can be reversed by cyclopamine. Nature 406: 1005-9 [PMID:10984056]

175. Tanaka S, Akiyoshi T, Mori M, Wands JR and Sugimachi K. (1998) A novel frizzled gene identified in human esophageal carcinoma mediates APC/beta-catenin signals. Proc. Natl. Acad. Sci. U.S.A. 95 : 10164-9 [PMID:9707618]

176. Tauriello DV, Jordens I, Kirchner K, Slootstra JW, Kruitwagen T, Bouwman BA, Noutsou M, Rüdiger SG, Schwamborn K and Schambony A et al.. (2012) Wnt/ $\beta$-catenin signaling requires interaction of the Dishevelled DEP domain and $C$ terminus with a discontinuous motif in Frizzled. Proc. Natl. Acad. Sci. 
U.S.A. 109: E812-20 [PMID:22411803]

177. Teglund S and Toftgård R. (2010) Hedgehog beyond medulloblastoma and basal cell carcinoma.Biochim. Biophys. Acta 1805: 181-208 [PMID:20085802]

178. Terasaki H, Saitoh T, Shiokawa K and Katoh M. (2002) Frizzled-10, up-regulated in primary colorectal cancer, is a positive regulator of the WNT - beta-catenin - TCF signaling pathway. Int. J. Mol. Med. 9: 10712 [PMID:11786918]

179. Tickenbrock L, Schwäble J, Wiedehage M, Steffen B, Sargin B, Choudhary C, Brandts C, Berdel WE, Müller-Tidow $\mathrm{C}$ and Serve H. (2005) Flt3 tandem duplication mutations cooperate with Wnt signaling in leukemic signal transduction. Blood 105: 3699-706 [PMID:15650056]

180. Toftgård R. (2000) Hedgehog signalling in cancer. Cell Mol Life Sci 57: 1720-1731 [PMID:11130178]

181. Tokuhara M, Hirai M, Atomi Y, Terada M and Katoh M. (1998) Molecular cloning of human Frizzled-6. Biochem. Biophys. Res. Commun. 243: 622-7 [PMID:9480858]

182. Traiffort E, Charytoniuk DA, Faure $\mathrm{H}$ and Ruat M. (1998) Regional distribution of Sonic Hedgehog, patched, and smoothened mRNA in the adult rat brain. J. Neurochem. 70: 1327-30 [PMID:9489757]

183. Tremblay MR, Lescarbeau A, Grogan MJ, Tan E, Lin G, Austad BC, Yu LC, Behnke ML, Nair SJ and Hagel $\mathrm{M}$ et al.. (2009) Discovery of a potent and orally active hedgehog pathway antagonist (IPI-926)J. Med. Chem. 52: 4400-18 [PMID:19522463]

184. Tycko B, Li CM and Buttyan R. (2007) The Wnt/beta-catenin pathway in Wilms tumors and prostate cancers. Curr. Mol. Med. 7: 479-89 [PMID:17691963]

185. Ueno K, Hirata H, Hinoda $Y$ and Dahiya R. (2013) Frizzled homolog proteins, microRNAs and Wnt signaling in cancer. Int. J. Cancer 132: 1731-40 [PMID:22833265]

186. Ueno K, Hiura M, Suehiro Y, Hazama S, Hirata H, Oka M, Imai K, Dahiya R and Hinoda Y. (2008) Frizzled-7 as a potential therapeutic target in colorectal cancer. Neoplasia 10: 697-705 [PMID:18592008]

187. Uhlen M, Oksvold P, Fagerberg L, Lundberg E, Jonasson K, Forsberg M, Zwahlen M, Kampf C, Wester K and Hober S et al.. (2010) Towards a knowledge-based Human Protein Atlas. Nat. Biotechnol. 28: 1248-50 [PMID:21139605]

188. van Amerongen R and Berns A. (2006) Knockout mouse models to study Wnt signal transduction.Trends Genet. 22: 678-89 [PMID:17045694]

189. van Amerongen $R$ and Nusse R. (2009) Towards an integrated view of Wnt signaling in development. Development 136: 3205-14 [PMID:19736321]

190. van Es JH, Jay P, Gregorieff A, van Gijn ME, Jonkheer S, Hatzis P, Thiele A, van den Born M, Begthel H and Brabletz T et al.. (2005) Wnt signalling induces maturation of Paneth cells in intestinal crypts.Nat. Cell Biol. 7: 381-6 [PMID:15778706]

191. van Gijn ME, Blankesteijn WM, Smits JF, Hierck B and Gittenberger-de Groot AC. (2001) Frizzled 2 is transiently expressed in neural crest-containing areas during development of the heart and great arteries in the mouse. Anat. Embryol. 203: 185-92 [PMID:11303904]

192. van Helden YG, Godschalk RW, Heil SG, Bunschoten A, Hessel S, Amengual J, Bonet ML, von Lintig J, van Schooten FJ and Keijer J. (2010) Downregulation of Fzd6 and Cthrc1 and upregulation of olfactory receptors and protocadherins by dietary beta-carotene in lungs of Bcmo1-/- mice. Carcinogenesis 31: 1329-37 [PMID:20472610]

193. Varecza Z, Kvell K, Talabér G, Miskei G, Csongei V, Bartis D, Anderson G, Jenkinson EJ and Pongracz JE. (2011) Multiple suppression pathways of canonical Wnt signalling control thymic epithelial senescence. Mech. Ageing Dev. 132: 249-56 [PMID:21549744]

194. von Maltzahn J, Bentzinger CF and Rudnicki MA. (2012) Wnt7a-Fzd7 signalling directly activates the Akt/mTOR anabolic growth pathway in skeletal muscle. Nat. Cell Biol. 14: 186-91 [PMID:22179044]

195. Wang C, Wu H, Evron T, Vardy E, Han GW, Huang XP, Hufeisen SJ, Mangano TJ, Urban DJ and Katritch $V$ et al.. (2014) Structural basis for Smoothened receptor modulation and chemoresistance to anticancer drugs. Nat Commun 5: 4355 [PMID:25008467]

196. Wang C, Wu H, Katritch V, Han GW, Huang XP, Liu W, Siu FY, Roth BL, Cherezov V and Stevens RC. (2013) Structure of the human smoothened receptor bound to an antitumour agent. Nature 497: 338-43 
[PMID:23636324]

197. Wang HQ, Xu ML, Ma J, Zhang $Y$ and Xie CH. (2012) Frizzled-8 as a putative therapeutic target in human lung cancer. Biochem. Biophys. Res. Commun. 417: 62-6 [PMID:22138402]

198. Wang J, Mook Jr RA, Lu J, Gooden DM, Ribeiro A, Guo A, Barak LS, Lyerly HK and Chen W. (2012) Identification of a novel Smoothened antagonist that potently suppresses Hedgehog signaling. Bioorg. Med. Chem. 20: 6751-7 [PMID:23063522]

199. Wang Y, Guo N and Nathans J. (2006) The role of Frizzled3 and Frizzled6 in neural tube closure and in the planar polarity of inner-ear sensory hair cells. J. Neurosci. 26: 2147-56 [PMID:16495441]

200. Wang Y, Huso D, Cahill H, Ryugo D and Nathans J. (2001) Progressive cerebellar, auditory, and esophageal dysfunction caused by targeted disruption of the frizzled-4 gene. J. Neurosci. 21: 4761-71 [PMID:11425903]

201. Wang Y, Macke JP, Abella BS, Andreasson K, Worley P, Gilbert DJ, Copeland NG, Jenkins NA and Nathans J. (1996) A large family of putative transmembrane receptors homologous to the product of the Drosophila tissue polarity gene frizzled. J. Biol. Chem. 271: 4468-76 [PMID:8626800]

202. Wang Y, Thekdi N, Smallwood PM, Macke JP and Nathans J. (2002) Frizzled-3 is required for the development of major fiber tracts in the rostral CNS. J. Neurosci. 22: 8563-73 [PMID:12351730]

203. Wang YK, Samos CH, Peoples R, Pérez-Jurado LA, Nusse R and Francke U. (1997) A novel human homologue of the Drosophila frizzled wnt receptor gene binds wingless protein and is in the Williams syndrome deletion at 7q11.23. Hum. Mol. Genet. 6: 465-72 [PMID:9147651]

204. Wang YK, Spörle R, Paperna T, Schughart K and Francke U. (1999) Characterization and expression pattern of the frizzled gene Fzd9, the mouse homolog of FZD9 which is deleted in Williams-Beuren syndrome. Genomics 57: 235-48 [PMID:10198163]

205. Wang Z, Shu W, Lu MM and Morrisey EE. (2005) Wnt7b activates canonical signaling in epithelial and vascular smooth muscle cells through interactions with Fzd1, Fzd10, and LRP5. Mol. Cell. Biol. 25: 502230 [PMID:15923619]

206. Wei $\mathrm{J}$ and Hemmings GP. (2004) Lack of a genetic association between the frizzled-3 gene and schizophrenia in a British population. Neurosci. Lett. 366: 336-8 [PMID:15288446]

207. Weierstall U, James D, Wang C, White TA, Wang D, Liu W, Spence JC, Bruce Doak R, Nelson G and Fromme $\mathrm{P}$ et al.. (2014) Lipidic cubic phase injector facilitates membrane protein serial femtosecond crystallography. Nat Commun 5: 3309 [PMID:24525480]

208. Willert K, Brown JD, Danenberg E, Duncan AW, Weissman IL, Reya T, Yates 3rd JR and Nusse R. (2003) Wnt proteins are lipid-modified and can act as stem cell growth factors. Nature 423: 448-52 [PMID:12717451]

209. Willert K and Nusse R. (2012) Wnt proteins.Cold Spring Harb Perspect Biol 4: a007864 [PMID:22952392]

210. Willert KH. (2008) Isolation and application of bioactive Wnt proteins.Methods Mol. Biol. 468: 17-29 [PMID:19099243]

211. Winn RA, Marek L, Han SY, Rodriguez K, Rodriguez N, Hammond M, Van Scoyk M, Acosta H, Mirus J and Barry N et al.. (2005) Restoration of Wnt-7a expression reverses non-small cell lung cancer cellular transformation through frizzled-9-mediated growth inhibition and promotion of cell differentiation. J. Biol. Chem. 280: 19625-34 [PMID:15705594]

212. Witze ES, Litman ES, Argast GM, Moon RT and Ahn NG. (2008) Wnt5a control of cell polarity and directional movement by polarized redistribution of adhesion receptors. Science 320: 365-9 [PMID:18420933]

213. Wright SC, Cañizal MCA, Benkel T, Simon K, Le Gouill C, Matricon P, Namkung Y, Lukasheva V, König GM and Laporte SA et al.. (2018) $\mathrm{FZD}_{5}$ is a $\mathrm{Ga}_{\mathrm{q}}$-coupled receptor that exhibits the functional hallmarks of prototypical GPCRs. Sci Signal 11: [PMID:30514810]

214. Wright SC, Kozielewicz P, Kowalski-Jahn M, Petersen J, Bowin CF, Slodkowicz G, Marti-Solano M, Rodríguez D, Hot B and Okashah N et al.. (2019) A conserved molecular switch in Class F receptors regulates receptor activation and pathway selection. Nat Commun 10: 667 [PMID:30737406]

215. Wu QL, Zierold C and Ranheim EA. (2009) Dysregulation of Frizzled 6 is a critical component of B-cell 
leukemogenesis in a mouse model of chronic lymphocytic leukemia. Blood 113: 3031-9 [PMID:19179304]

216. Xie J, Murone M, Luoh SM, Ryan A, Gu Q, Zhang C, Bonifas JM, Lam CW, Hynes M and Goddard Aet al.. (1998) Activating Smoothened mutations in sporadic basal-cell carcinoma.Nature 391: 90-2 [PMID:9422511]

217. Xu L, Tan L, Goldring MB, Olsen BR and Li Y. (2001) Expression of frizzled genes in mouse costochondral chondrocytes. Matrix Biol. 20: 147-51 [PMID:11334716]

218. Xu Q, Wang Y, Dabdoub A, Smallwood PM, Williams J, Woods C, Kelley MW, Jiang L, Tasman W and Zhang $\mathrm{K}$ et al.. (2004) Vascular development in the retina and inner ear: control by Norrin and Frizzled-4, a high-affinity ligand-receptor pair. Cell 116: 883-95 [PMID:15035989]

219. Yamada M, Iwabuchi T, Takahashi K, Kurahashi C, Ohata H, Honda K, Higuchi T and Yamada M. (2005) Identification and expression of frizzled-3 protein in rat frontal cortex after antidepressant and electroconvulsive treatment. J. Pharmacol. Sci. 99: 239-46 [PMID:16258230]

220. Yanfeng WA, Tan C, Fagan RJ and Klein PS. (2006) Phosphorylation of frizzled-3.J. Biol. Chem. 281: 11603-9 [PMID:16513654]

221. Yang J, Si T, Ling Y, Ruan Y, Han Y, Wang X, Zhang H, Kong Q, Li X and Liu @t al.. (2003) Association study of the human FZD3 locus with schizophrenia. Biol. Psychiatry 54: 1298-301 [PMID:14643098]

222. Yang L, Wu X, Wang Y, Zhang K, Wu J, Yuan YC, Deng X, Chen L, Kim CC and Lau \$t al.. (2011) FZD7 has a critical role in cell proliferation in triple negative breast cancer. Oncogene 30: 4437-46 [PMID:21532620]

223. Yang S, Wu Y, Xu TH, de Waal PW, He Y, Pu M, Chen Y, DeBruine ZJ, Zhang B and Zaidi Sket al.. (2018) Crystal structure of the Frizzled 4 receptor in a ligand-free state. Nature 560: 666-670 [PMID:30135577]

224. Ye X, Wang Y, Cahill H, Yu M, Badea TC, Smallwood PM, Peachey NS and Nathans J. (2009) Norrin, frizzled-4, and Lrp5 signaling in endothelial cells controls a genetic program for retinal vascularization. Cell 139: 285-98 [PMID:19837032]

225. Ye X, Wang Y, Rattner A and Nathans J. (2011) Genetic mosaic analysis reveals a major role for frizzled 4 and frizzled 8 in controlling ureteric growth in the developing kidney. Development 138: 1161-72 [PMID:21343368]

226. Yoshida S, Arita R, Yoshida A, Tada H, Emori A, Noda Y, Nakao S, Fujisawa K and Ishibashi T. (2004) Novel mutation in FZD4 gene in a Japanese pedigree with familial exudative vitreoretinopathy. Am. J. Ophthalmol. 138: 670-1 [PMID:15488808]

227. You J, Nguyen AV, Albers CG, Lin F and Holcombe RF. (2008) Wnt pathway-related gene expression in inflammatory bowel disease. Dig. Dis. Sci. 53: 1013-9 [PMID:17939044]

228. Yu H, Smallwood PM, Wang Y, Vidaltamayo R, Reed R and Nathans J. (2010) Frizzled 1 and frizzled 2 genes function in palate, ventricular septum and neural tube closure: general implications for tissue fusion processes. Development 137: 3707-17 [PMID:20940229]

229. Yu H, Ye X, Guo N and Nathans J. (2012) Frizzled 2 and frizzled 7 function redundantly in convergent extension and closure of the ventricular septum and palate: evidence for a network of interacting genes. Development 139: 4383-94 [PMID:23095888]

230. Zerlin M, Julius MA and Kitajewski J. (2008) Wnt/Frizzled signaling in angiogenesis.Angiogenesis 11: 63-9 [PMID:18253847]

231. Zhang X, Zhao F, Wu Y, Yang J, Han GW, Zhao S, Ishchenko A, Ye L, Lin X and Ding let al.. (2017) Crystal structure of a multi-domain human smoothened receptor in complex with a super stabilizing ligand. Nat Commun 8: 15383 [PMID:28513578]

232. Zhang XM, Ramalho-Santos M and McMahon AP. (2001) Smoothened mutants reveal redundant roles for Shh and Ihh signaling including regulation of $L / R$ asymmetry by the mouse node. Cell 105: 781-92 [PMID:11440720]

233. Zhang Y, Yu X, Yuan Y, Ling Y, Ruan Y, Si T, Lu T, Wu S, Gong X and Zhu Zet al.. (2004) Positive association of the human frizzled 3 (FZD3) gene haplotype with schizophrenia in Chinese Han population. Am. J. Med. Genet. B Neuropsychiatr. Genet.129B: 16-9 [PMID:15274031] 
234. Zhao C, Avilés C, Abel RA, Almli CR, McQuillen P and Pleasure SJ. (2005) Hippocampal and visuospatial learning defects in mice with a deletion of frizzled 9 , a gene in the Williams syndrome deletion interval. Development 132: 2917-27 [PMID:15930120]

235. Zhao $C$ and Pleasure SJ. (2005) Frizzled9 protein is regionally expressed in the developing medial cortical wall and the cells derived from this region. Brain Res. Dev. Brain Res. 157: 93-7 [PMID:15939089]

236. Zhao Z, Lee CC, Baldini A and Caskey CT. (1995) A human homologue of the Drosophila polarity gene frizzled has been identified and mapped to 17q21.1. Genomics 27: 370-3 [PMID:7558010] 